\title{
RELASI YAHUDI DAN NABI MUHAMMAD DI MADINAH: Pengaruhnya terhadap Politik Islam
}

\author{
Khoirul Anwar \\ Lembaga Studi Sosial dan Agama (eLSA) Semarang \\ e-mail: khoirulanwar_88@yahoo.co.id
}

\begin{abstract}
This paper describes how is the relationship between the Prophet Muhammad and the Jews of Medina reciprocally, as well as its influence on the political concepts that defined by the Prophet Muhammad. The political interests for the both relations cause the inception of harmony and disharmony state. The relation between the Prophet Muhammad and the Jews became different along with the changes of the desired political interests respectively. Besides that, the Jews in Medina had a lot of contribution to the Prophet Muhammad to realize the power stipulation stretched in all Arabian peninsula until he died. Although the prophet's success is not entirely of the Jews, but the Jewish contribution may not be overlooked.
\end{abstract}

\section{[1]}

Tulisan ini memaparkan bagaimana relasi Nabi Muhammad dengan Yahudi di Madinah sebagai relasi timbal balik, serta pengaruhnya terhadap konsep politik yang ditetapkan Nabi Muhammad. Kepentingan politik dalam relasi keduanya menjadi sebab yang melahirkan keadaan harmoni dan disharmoni. Relasi Nabi Muhammad dan Yahudi berubah seiring dengan berubahnya kepentingan politik yang dikehendaki masingmasing. Disamping itu, orang-orang Yahudi di Madinah banyak berkontribusi terhadap Nabi Muhammad dalam mewujudkan kekuasaan yang ditetapkannya hingga menjelang Nabi wafat, kekuasaannya terbentang di seluruh wilayah Jazirah Arab. Meskipun keberhasilan Nabi tidak seluruhnya dari Yahudi, namun kontribusi Yahudi dalam hal ini tak bisa disepelekan.

Keywords: Quraish; Nabi Muhammad; Yahudi; politik; hukum 


\section{Pendahuluan}

Sejarah mendeskripsikan bahwa Nabi Muhammad bukan hanya sebagai pemimpin agama yang mengajak umat manusia untuk menyembah Tuhan dan menjalankan ritual tertentu, tapi juga sebagai orang yang berhasil membangun kekuasaan ${ }^{1}$ di Jazirah Arab. Kekuasaannya terbentang dari Arab bagian selatan hingga utara dengan menjadikan Madinah sebagai pusat pemerintahannya. ${ }^{2}$

Sejak awal muatan politik dalam dakwah Nabi Muhammad sudah dipahami oleh orang-orang di sekitarnya. Sejarawan Muslim klasik Ibn al-Athīr (w. 630 H) dalam bukunya al-Kämil fi ' l-Tārikhh, menginformasikan tentang hal ini melalui kisah 'Afif al-Kindī, seorang pedagang yang datang ke Makkah pada musim haji. Di Makkah, 'Afif menyaksikan seorang lelaki bersama istrinya dan anak kecil melaksanakan shalat menghadap Ka'bah. 'Afif bertanya kepada 'Abbās ibn Abdul Muthalib: "Wahai 'Abbās, agama apa ini?” Abbās menjawab:

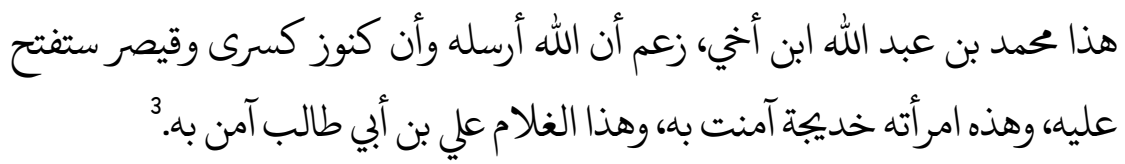

"Ini adalah Muhammad ibn Abdillah, keponakanku. Ia menduga bahwa Allah telah mengutusnya, dan harta kekayaan Kisrā (Persi) dan Qaishar (Romawi) akan ditaklukkan. Sedangkan wanita ini adalah Khadījah yang beriman kepadanya, dan anak kecil ini Alī ibn Abī Ṭālib juga beriman kepadanya."

Riwayat di atas menjelaskan bahwa sejak awal, dapat dipahami bahwa gerakan Nabi merupakan gerakan politik yang mempunyai keinginan untuk menaklukkan dua kerajaan besar saat itu, yakni Persi dan Romawi.

\footnotetext{
1Dalam tulisan ini penulis dalam satu kesempatan menggunakan istilah "kekuasaan", dalam kesempatan lain menggunakan istilah "negara" untuk menyebut "kekuasaan" yang menjadi pembahasan dalam tulisan ini. Dua istilah ini sengaja penulis gunakan secara bergantian supaya tidak terjebak dalam perdebatan apakah kekuasaan yang dimiliki Nabi Muhammad bisa masuk dalam cakupan definisi negara atau bukan. Terlepas dari perdebatan itu, jika berpijak pada teori terjadinya negara secara primer (primaire staats wording) maka akan didapati bahwa kekuasaan Quraish dapat disebut negara atau minimal cikal bakal negara. Lihat Abu Daud Busrah, Ilmu Negara, cet. VII (Jakarta: Bumi Aksara, 2010,), h. 44-46.

2Fathiyyah al-Nabrāwī dan Muhammad Nashr Mihnā, Tațawwur al-Fikr al-Siyāsī fi T-Islām, vol. II , cet. I (Kairo: Dār al-Maāāif, 1984), h. 28-29.

3Ibn al-Athīr, al-Kāmilfi al-Tārīkh, vol. I, cet. I (Beirut: Dār al-Kitāb al-'Arabi, 1997), h. 655.
} 
Dalam meraih kekuasaan politiknya, Nabi Muhammad harus menghadapi berbagai rintangan, dari mulai penolakan berupa perkataan hingga tindakan yang mengarah pada pertumpahan darah. Kekuasaan Nabi bukan berdiri dalam waktu yang singkat atau secara tiba-tiba, tapi telah melewati waktu yang sangat lama dan ada banyak orang yang terlibat di dalamnya.

Misi politik ini yang menjadikan para pemuka Quraish menolak dakwah Nabi Muhammad. Penolakan ini bukan karena tidak setuju dengan seruan meng-esa-kan Tuhan (tawhìd) yang dibawanya, melainkan karena cita-citanya yang menghendaki kekuasaan berada di dalam genggamannya.

Bagi suku Quraish, konsep ketuhanan yang diperkenalkan Nabi Muhammad bukan hal yang asing. Dalam waktu yang sangat lama suku Quraish sudah mengenal ajaran tawhìd dari orang-orang Yahudi. Yakni sejak Makkah menjadi tempat transit perdagangan (sekitar abad $5 \mathrm{M}$ ), dan kemudian penduduknya ikut serta melakukan perjalanan dagang, orang-orang Quraish berjumpa dengan orang-orang Yahudi yang menurut Khalī Abdul Karīm (w. 2002 M), memiliki peradaban dan ilmu pengetahuan yang lebih maju. ${ }^{4}$

Beberapa ayat al-Qur'an yang turun di Makkah memberikan pemahaman bahwa orang-orang Quraish dan Nabi Muhammad sangat dekat dengan tradisi-tradisi Yahudi. Pembahasan tentang Bani Israel, Musa, Fir'aun, dan ajaran-ajaran Yahudi lainnya banyak disampaikan al-Qur'an ketika berhadapan dengan orang-orang Quraish di Makkah, seperti QS. al-Shu'arā: 197, QS. alAhqāf: 10, dan QS. al-Mā'idah: 48.

Ada banyak teori terutama yang ditawarkan sarjana Barat tentang pengaruh Yahudi terhadap ajaran Nabi Muhammad, antara lain karena Nabi membaca Taurat. Teori demikian meniscayakan pemaknaan lain terhadap kata ummiy yang disematkan kepada Nabi Muhammad. Jika ummiy sering diartikan sebagai tidak bisa baca tulis, maka pengguna teori ini menafsirkannya sebagai "Nabi yang diutus kepada masyarakat yang tidak memiliki kitab suci." ${ }^{5}$

\footnotetext{
${ }^{4}$ Khalī ‘Abdul Karīm, Quraish min I-Qabīlah ilā T-Dawlah al-Markaziyyah, cet. II (Kairo: Sinnā li alNasyr, 1997), h. 155.

5Mun'im Sirry, Kontroversi Islam Awal: Antara Mazhab Tradisionalis dan Revisionis, cet. I (Bandung: Mizan Pustaka, 2015), h. 85-86.
} 
Teori lain seperti disampaikan W. Montgomery Watt (w. 2006 M), bahwa ajaran-ajaran Yahudi diterima Nabi melalui intelektual-intelektual Makkah. Perjumpaan suku Quraish dengan orang-orang Yahudi dalam rentang waktu yang cukup lama (sejak abad ke 5-6 M) memberikan dampak pada alam pemikiran suku Quraish yang terpengaruh oleh tradisi-tradisi Yahudi. ${ }^{6}$

Kesimpulan Watt lebih bisa diterima jika melihat genealogi kekuasaan Nabi Muhammad atau yang disebut Khalī Abdul Karīm dengan "kekuasaan Quraish (dawlat Quraish)".7 Menurut Khalīl, kekuasaan yang diraih Nabi Muhammad pada dasarnya sudah dipersiapkan oleh nenek moyangnya sejak Qushaiy ibn Kilāb (w. 480 M), sehingga posisi Nabi di dalam kekuasaan Quraish bukan sebagai "pendiri", melainkan sebagai orang yang melanjutkan cita-cita besar nenek moyangnya. ${ }^{8}$ Karena itu menunjukkan relasi nenek moyang Nabi Muhammad dengan Yahudi sangat urgen sebelum melihat potret relasi Nabi Muhammad sendiri dengan kelompok masyarakat Yahudi.

Orang-orang Yahudi dalam literatur Islam seringkali dinarasikan sebagai kelompok yang bengis, penentang Nabi, dan segala keburukan lainnya. Pandangan demikian terus berlanjut hingga sekarang tanpa ada klarifikasi sejarah pergumulan masyarakat Arab, khususnya suku Quraish, Nabi Muhammad, dan Yahudi secara objektif.

Zulkarnaini Abdullah dalam penelitiannya tentang Yahudi dalam al-Qur'an menyimpulkan, kebencian umat Islam terhadap Yahudi sejak dahulu hingga sekarang yang juga menyeruak dalam literatur-literatur keislaman, pada dasarnya bukan bersumber dari al-Qur'an. Begitu juga dengan kejahatankejahatan yang kerap dituduhkan kepada Yahudi sebenarnya tidak sejalan dengan semangat kitab suci umat Islam. ${ }^{9}$

Interaksi suku Quraish, Nabi Muhammad, dan Yahudi dalam tulisan ini dilihat sebagai pergumulan politik yang masing-masing memiliki kepentingan

6W. Montgomery Watt, Muhammad Prophet and Statesman, diindonesiakan oleh A. Asnawi, Muhammad Sang Negarawa, cet. I (Jogjakarta: Diglossia, 2007), h. 56-59.

${ }^{7}$ Khalil'AAbdul Karīm, Quraish min I-Qabïlah ilā I-Dawlah al-Markaziyyah, h. 30.

8 Ibid.

9Zulkarnaini Abdullah, Yahudi dalam al-Qur'an; Teks, Konteks, dan Diskursus Pluralisme Agama (Yogyakarta: Penerbit eLSAQ Press, 2007, cet. I), h. 359. 
berupa kekuasaan. Untuk mempertajam pembahasan, kajian ini bertujuan untuk melihat interaksi yang terjadi antara nenek moyang Nabi Muhammad (suku Quraish) dengan Yahudi, hingga kemudian berpengaruh terhadap Nabi Muhammad dan ajarannya. Karena Yahudi seperti dijelaskan Khalil Abdul Karīm, memiliki peradaban yang lebih maju. Sehingga tidak heran jika kemudian dalam episode kehidupan Nabi Muhammad juga tidak lepas dari kehadiran orang-orang Yahudi.

\section{Kondisi Sosial, Ekonomi dan Politik Yahudi di Madinah}

Sebelum Nabi Muhammad beserta pengikutnya hijrah ke Madinah, di wilayah ini ada tiga suku besar yang sedang dilanda persaingan ekonomi dan politik, yaitu Yahudi, suku Aus, dan suku Khazraj. Yahudi sebagai penduduk pertama di Madinah, selain keluarga-keluarga Arab kecil yang tinggal lebih dahulu, memiliki kekayaan yang sangat banyak. Setelah dua suku bersaudara datang, yaitu suku Aus dan Khazraj, kekayaan Yahudi berkurang lantaran direbut oleh kedua suku ini melalui pertempuran.

Seiring berjalannya waktu, suku Aus dan Khazraj dilanda konflik yang akar masalahnya tidak lepas dari perebutan lahan ekonomi. Demikian pula, orangorang Yahudi juga tidak satu suara, yakni terjadi konflik di antara keluargakeluarga Yahudi. Hal ini menjadikan orang-orang Yahudi ada yang mengadakan perjanjian damai (muhālafāt) dengan suku Aus, juga ada yang memilih berdamai dengan suku Khazraj.

Masing-masing pemeluk Yahudi ikut serta terlibat dalam peperangan yang dilakukan suku Aus dan Khazraj. Perang dua suku bersaudara ini berlangsung selama 120 tahun yang berakhir dengan terjadinya perang Bi'āth (yaum bi'āth). Dalam perang ini, suku Aus dibantu orang-orang Yahudi yang mengadakan perjanjian damai dengannya mengalahkan suku Khazraj dan sekutunya, yakni orang Yahudi yang berdamai dengannya, hingga Khazraj kehilangan banyak orang dan harta benda. ${ }^{10}$

\footnotetext{
${ }^{10}$ Nāshir al-Sayyid, Yahūdu Yathrib wa Khaibar: al-Ghazawāt wa I-Shirā, cet. I (Beirut: al-Maktabah al-Thaqāfiyyah, 1992), h. 26-27.
} 
Dalam pertempuran ini Yahudi Bani al-Naḍīr dan Quraiḍah menyerang Yahudi Bani Qainuqā' hingga keberadaan Bani Qainuqā' tercerai berai sebagaimana kabilah Khazraj yang juga kalah telak oleh suku Aus. ${ }^{11}$ Peperangan ini sungguh meninggalkan luka mendalam di hati orang-orang Khazraj, hingga pada masa Nabi Muhammad dendam lama kembali dimunculkan.

Di Madinah meski dalam sejarahnya orang-orang Yahudi telah dikalahkan suku Aus dan suku Khazraj, namun secara ekonomi dan politik, orang-orang Yahudi memiliki pengaruh besar. Yahudi di tempat ini selain sebagai tuan tanah, juga secara umum memiliki berbagai keahlian yang dapat mendatangkan materi, seperti industri, dan berdagang. Orang-orang dari suku Aus, Khazraj, dan kabilah-kabilah kecil di Madinah banyak yang bekerja kepada Yahudi, terutama dalam mengelola pertanian. ${ }^{12}$

Namun seiring dengan konflik yang terus terjadi di antara orang-orang Yahudi, maupun konflik antar suku yang melibatkan orang Yahudi, kekayaan yang dimiliki Yahudi berkurang, bahkan ada sebagian Yahudi yang tidak memiliki tanah. Hal ini seperti yang menimpa Yahudi Bani Qainuqā'. Entah apa penyebabnya, Yahudi Bani Qainuqā’ meninggalkan tanah dan tanamannya, dan hanya mengandalkan kerja industri (al-shinā'ah). Karena itu ketika Nabi Muhammad mengusir keluarga Yahudi Bani Qainuqā', keluarga ini tidak memiliki tanah dan sawah. ${ }^{13}$

Secara umum peta politik di Madinah lebih rumit daripada di Makkah yang hanya ada dua kubu, yakni suku Quraish dengan kepentingan dagangnya, dan kubu Nabi Muhammad beserta pengikutnya yang sedang berusaha meraih kekuasaan sebagaimana para leluhurnya, bahkan lebih dari itu.

Yahudi Madinah memiliki kepentingan serupa dengan para pemuka Quraish, yakni ekonomi. Hanya saja ekonomi di Madinah kalah saing dengan perekonomian Makkah. Masyarakat Madinah yang tercerai berai dan saling bersaing serta menyimpan dendam sangat merindukan sosok pemersatu yang

\footnotetext{
${ }^{11}$ Ahmad Ibrāhīm al-Sharīf, Makkah wa T-Madīnah fi I-Jāhiliyyah wa 'Ahdi al-Rasūl (Beirut: Dār alFikr al-'Arabi, t.th.), h. 346.

12 Ibid, h. 348.

13Ibid, h. 347.
} 
pada gilirannya dapat mengantarkan perekonomian di Madinah dapat mengalahkan Makkah, yakni sebagai pusat perdagangan internasional.

Ketika Yahudi Madinah mendengar gerakan Nabi Muhammad di Makkah dari orang-orang yang berbaiat kepada Nabi di 'Aqabah,14 Yahudi sangat berharap Nabi Muhammad pindah ke Madinah dan bergabung dengan kelompok Yahudi. Bagi Yahudi, dakwah Nabi dan ajaran yang diserukannya sama dengan ajaran-ajaran Yahudi. Karena itu Yahudi merencanakan jika Muhammad hijrah ke Madinah, maka Muhammad akan dimasukkan ke dalam agama Yahudi untuk bersama-sama menghilangkan ritual menyembah berhala.

Selain itu Yahudi Madinah berharap kepada Muhammad dapat menjadi penghimpun kabilah-kabilah di Madinah supaya bersatu padu menciptakan ketenangan dan kenyamanan Kota Madinah. Jika sudah demikian, maka Madinah dapat menjadi pusat perdagangan internasional yang bisa mengalahkan Makkah. ${ }^{15}$

Harapan dan rencana Yahudi sampai kepada Nabi Muhammad melalui orang-orang yang berbaiat kepada Nabi di 'Aqabah setelah bai'at yang pertama. Informasi demikian segera direspon Nabi dengan perhitungan bahwa umat atau pengikut Nabi akan bertambah banyak. Hal ini bisa menjadi modal utama untuk melawan orang-orang Quraish, sehingga cita-cita besar Nabi dapat terlaksana, yakni membangun kekuasaan yang terbentang di semua penjuru bumi.

\footnotetext{
${ }^{14}$ Orang-orang Madinah yang berbaiat pertama kepada Nabi Muhammad di 'Aqabah (ahl al'aqabah al-ülā) ketika kembali ke Madinah mengirim surat kepada Nabi yang berisi permintaan supaya Nabi mengutus seseorang yang bisa memberikan pemahaman dalam agama dan membacakan al-Qur'an. Dalam penggalan surat itu tertulis:

$$
\text { إبعث إلينا رجلا يفقهنا في الدين، ويقرئنا القرألس||[|| }
$$

"Delegasikanlah kepada kami seorang lelaki yang bisa mengajarkan agama, dan membacakan alQur'an kepada kami."

Menanggapi permintaan dari pengikut Nabi di Madinah (sahabat Anșār), Nabi Muhammad mendelegasikan Mush'ab ibn 'Umair. Isi surat lengkap ini tidak terdokumentasikan oleh para sejarawan. Lihat Muhammad H̦umaidullāh, Majmū'ah al-Wathā ïq al-Siyāsiyyah li al-'Ahdi al-Nabawiy wa al-Khilāfah al-Rāsyidah, cet VI (Beirut: Dār al-Nafā iss, 1987), h. 52.

${ }^{15}$ Israel Wolfensohn, Tārīkh al-Yahūd fi Bilād al-'Arab fi T-Jāhiliyyah wa Shadr al-Islām (Mesir: Mațba’ah al-I'timād bi Syāri' Hasan al-Akbar, 1927), h. 11.
} 
Nabi Muhammad memanfaatkan informasi itu dengan baik karena selain Nabi Muhammad sendiri sebagai keturunan Yathrib dari jalur kakeknya (Abdul Muțalib), Nabi juga mengetahui bahwa Yahudi di Madinah memiliki kelas sosial yang tinggi dalam peradaban, ekonomi, maupun politik. Nabi Muhammad yakin bahwa dirinya di Madinah dapat mengajak orang Yahudi untuk mengikuti dakwahnya yang secara esensial selaras dengan yang diajarkan para leluhur Bani Israel. ${ }^{16}$

Dengan menggalang massa seperti ini, Nabi Muhammad dapat menyatukan semua penduduk Madinah yang patuh kepada kepemimpinannya. Di sini Nabi dapat mendirikan kekuasaan yang dikemudian hari, rencana menguasai dua imperium besar saat itu (Persi dan Romawi) bisa tergapai.

\section{Perjanjian Damai Nabi Muhammad dengan Penduduk Madinah}

Kedatangan Nabi Muhammad di Madinah disambut baik oleh penduduknya, termasuk orang-orang Yahudi yang sudah lama mengharapkan kedatangannya. Ibnu Hishām meriwayatkan, bahwa orang Madinah yang pertama kali melihat kedatangan Nabi yaitu orang Yahudi yang sudah lama menunggu. Menyaksikan kedatangan Nabi, orang Yahudi itu berteriak: "Wahai Bani Qailah, ini kakek kalian telah datang (يا بني قيلة، هذا جدمقد جاء)."17

Setelah membaca kondisi sosial, ekonomi, dan politik Madinah, Nabi Muhammad segera melakukan strategi politiknya dengan mengadakan perjanjian damai (mu'âhadah) dengan berbagai keluarga Yahudi dan lainnya di Madinah. Perjanjian damai yang dilakukan Nabi Muhammad terjadi berulangkali sesuai dengan kebutuhan politiknya, yakni sebagai strategi untuk mencari perlindungan, bantuan, dan keamanan jiwa maupun harta. ${ }^{18}$

Masa-masa awal di Madinah, Nabi sangat membutuhkan pertolongan dan perlindungan dari kejaran orang-orang Quraish. Dalam hal ini Nabi meng-

\footnotetext{
16Ibid, h. 11-12.

${ }^{17}$ Ibn Hishām, al-Sirah al-Nabawiyyah, cet. II, vol. I (Mesir: Syirkah Maktabah wa Maṭba'ah Mushțafãal-Bābī al-Halbī, 1955), h. 492.

${ }^{18}$ Israel Wolfensohn, Tārīkh al-Yahūd fi Bilād al-Arab fi I-Jāhiliyyah wa Ṣadr al-Islām (Mesir: Mațba'ah al-I'timād bi Shāri' Ḥasan al-Akbar, 1927), h. 115.
} 
haruskan mengadakan perjanjian damai dengan Yahudi yang memiliki kekuasaan dan berbagai bidang lainnya di Madinah. ${ }^{19}$

Israel Wolfensohn menginformasikan, perjanjian damai Nabi Muhammad dengan Yahudi terjadi berulangkali. Nabi melakukan perjanjian damai hanya dengan Banī Quraiḍah. Nabi membuat kesepakatan damai dengan Yahudi Khaibar, Yahudi Taimā’, dan Yahudi Wādī al-Qurā. Nabi juga berulangkali mengadakan perjanjian damai dengan Yahudi Bani Ghudyah, dan keluargakeluarga Yahudi terpandang lainnya. ${ }^{20}$

Namun sayangnya kesepakatan-kesepakatan Nabi Muhammad dengan orang-orang Yahudi dari berbagai keluarga dan suku itu tidak terdokumentasikan oleh sejarawan secara lengkap. Dokumen lengkap kesepakatan Nabi yang tertulis dalam buku-buku sejarah hanya kesepakatan yang disebut dengan "Piagam Madinah (Watsiqqah al-Madīnah)" ${ }^{21}$

Kendati demikian, Piagam Madinah cukup dijadikan bukti bahwa Nabi Muhammad ketika hijrah ke Madinah telah melakukan perjanjian damai dengan berbagai suku dan keluarga Yahudi, serta penduduk Madinah lainnya. Juga perjanjian damai yang dilakukannya tidak hanya terjadi sekali, melainkan berulangkali sesuai dengan kebutuhan politiknya. Ini yang menjadikan narasi kehidupan Yahudi di Madinah pasca Nabi Muhammad hijrah sesekali terlihat sangat berdamai dengan Nabi, dan sesekali sangat bermusuhan.

Wolfensohn mengatakan:

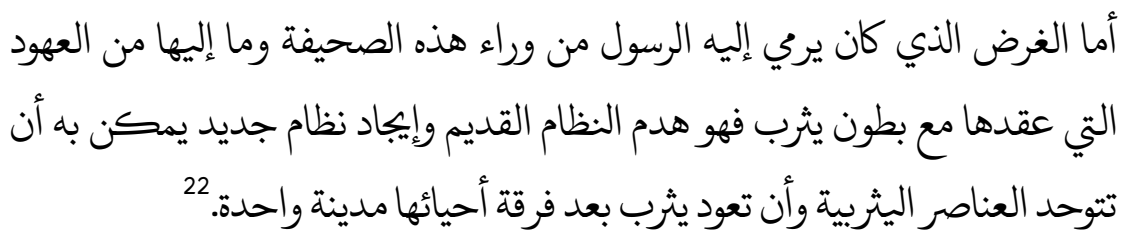

"Tujuan yang hendak digapai Nabi Muhammad dalam mengadakan berbagai perjanjian damai dengan keluarga-keluarga di Yathrib yaitu untuk meruntuh-

\footnotetext{
${ }^{19}$ Ibid.

${ }^{20}$ Ibid.

${ }^{21}$ Lihat dokumen Piagam Madinah.

${ }^{22}$ Israel Wolfensohn, Tārīkh al-Yahūd fi Bilād al-'Arab fi I-Jāhiliyyah wa Șadr al-Islām, h.116.
} 
kan sistem lama dan menciptakan sistem baru yang dapat menyatukan semua unsur di Yathrib, dan mengembalikan Yathrib menjadi kota yang satu setelah keluarga-keluarganya (penduduknya) tercerai berai."

Sistem pemerintahan di Madinah ada di dalam benteng. Dalam distrik yang di dalamnya terdapat ladang pertanian dan tempat hunian para pemilik tanah beserta pekerjanya, benteng menjadi milik bersama. Yakni para pekerja dan buruh tani sebagai orang merdeka ikut serta memiliki hak atas benteng sebagaimana tuan tanah yang kebanyakan orang-orang Yahudi. Sedangkan hamba sahaya hanya memiliki sedikit hak atas benteng itu.

Sedangkan dalam distrik lain, kekuasaan atas benteng hanya dimiliki keluarga tertentu, yakni keluarga dari keturunan mulia, meskipun di dalam distrik dihuni banyak keluarga. Penguasaan atas benteng dipegang oleh kepala keluarga terhormat.

Benteng pada masa kini penulis membayangkan seperti "ibu kota" di dalam distrik, yakni di dalamnya ada pasar, tempat penyimpanan harta benda, senjata, dan barang-barang dagangan. Selain itu di dalam benteng juga terdapat tempat ibadah Yahudi dan rumah untuk mengkaji midras.

Bentuk benteng yang melingkar dan berada di dataran tinggi berfungsi sebagai penjaga bagi orang-orang yang tinggal di dalamnya dari serangan musuh, dan menjadi tempat berlindung bagi keluarga yang sedang ketakutan dari orang-orang yang hendak menyerangnya, serta menjadi tempat pengungsian perempuan-perempuan ketika para suaminya pergi berperang. ${ }^{23}$

Keluarga yang besar (bațn min al-buțūn al-kabïrah) memegang kekuasaan atas keluarga-keluarga kecil (al-buțūn al-șaghïrah) yang mengadakan perjanjian damai dengannya. Dalam hal ini keluarga besar mempunyai kewajiban untuk melindungi keluarga-keluarga kecil dari serangan keluarga lain, juga ikut serta menuntut balasan apabila keluarga kecil dizalimi, dan memberikan denda (diyat) jika keluarga kecil yang berada dalam kekuasaannya melakukan tindak pidana.

Ketika keluarga besar sedang berperang, maka keluarga-keluarga kecil yang bersekutu dengannya harus ikut terlibat dalam peperangan. Jika tidak,

${ }^{23}$ Ibid, h. 116-117. 
maka dianggap sebagai pembangkangan. Keluarga-keluarga yang bersekutu juga mempunyai kewajiban untuk saling membantu, memberikan manfaat, dan menjaga eksistensi pemerintahan benteng ini dari gejolak eksternal, yakni berbagai kemungkinan serbuan dari pemerintah keluarga lain. ${ }^{24}$

Sistem independensi pemerintahan yang dimiliki masing-masing keluarga besar dan sekutunya di Madinah dipahami betul oleh Nabi Muhammad sejak masa-masa awal hijrah. Sehingga dengan mengadakan perjanjian damai bersama kepala-kepala keluarga yang mengendalikan pemerintahan di dalam sukunya masing-masing, Nabi Muhammad dapat menyatukan semua pemerintahan di Madinah menjadi satu pemerintahan yang berdiri di atas basis saling tolong menolong.

Ini yang disebut Wolfensohn sebagai langkah "meruntuhkan sistem pemerintahan lama (hadmu al-niz̄ām al-qadìm)" dengan mewujudkan "sistem pemerintahan baru (ïjādu nizāom jadīd)". Yakni meruntuhkan sistem independensi pemerintahan masing-masing keluarga, untuk kemudian disatukan ke dalam satu pemerintahan tunggal tanpa menghilangkan nilai-nilai yang mewajibkan antar kelompok yang ada di dalamnya untuk saling bahu membahu.

\section{Kontribusi Yahudi pada Masa Nabi Muhammad}

Sebagaimana yang terjadi pada diri Abdul Muțalib, ajaran-ajaran yang sumbernya dapat ditemukan dalam agama Yahudi juga terinternalisasi pada diri Nabi Muhammad melalui orang-orang yang merawat Nabi sejak kecil, yaitu Abdul Muțalib dan Abū Ṭāilib.

Sejak suku Quraish berinteraksi dengan orang-orang Yahudi, terutama pada masa Abdul Muțalib, paham ke-esa-an Tuhan terinternalisasi pada diri orang-orang Quraish. Hanya saja sebagian dari mereka banyak yang menjadikan patung sebagai sekutunya (musyrik). Orang-orang Quraish yang murni mengimani ke-esa-an Tuhan menyatakan bahwa dirinya sebagai pengikut tradisi Ibrahim (millah Ibrāhìm). Jhon C. Blair mengatakan, pengetahuan

\footnotetext{
${ }^{24}$ Ibid., h. 118-119.
} 
tentang ke-esa-an Tuhan telah menancap di hati masyarakat Arab melalui interaksinya dengan orang-orang Yahudi. ${ }^{25}$

Memang ada beberapa riwayat yang menginformasikan bahwa Muhammad sebelum menjadi Nabi mengikuti agama yang berkembang di kalangan orang-orang Quraish, yaitu menyembah berhala. Riwayat ini antara lain diceritakan Ibnu al-Kalbi dalam karyanya, Kitāb al-Așnām, bahwa pada suatu hari Nabi Muhammad pernah menceritakan hubungannya dengan salah satu berhala ternama pada masa pra Islam, yakni berhala 'Uzza. Nabi Muhammad mengatakan:

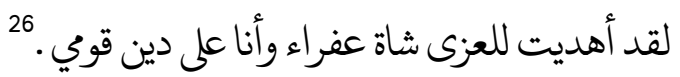

"Sungguh (pada saat itu) aku memberi hadiah kepada berhala 'Uzza berupa kambing putih, aku mengikuti agama kaumku."

Diinformasikan pula bahwa suatu ketika Muhammad mengajak Zaid ibn 'Amr, pengikut agama Hanīf, memakan binatang yang dipersembahkan untuk berhala. Kepada Muhammad, Zaid mengatakan bahwa dirinya tidak memakan hewan yang disembelih untuk persembahan terhadap berhala. Sementara Muhammad sendiri memakannya. ${ }^{27}$

Jika riwayat-riwayat ini benar, besar kemungkinan hal itu terjadi sebelum Nabi Muhammad memulai strategi politiknya dengan menggunakan agama. Ajaran agama yang diwariskan Abdul Muțalib dikemudian hari menjadi pondasi agama Nabi Muhammad yang terus mengalami perkembangan seiring dengan perjumpaannya dengan orang-orang Yahudi.

Kontribusi Yahudi terhadap agama Nabi Muhammad cukup besar, bahkan menempati ajaran-ajaran pokok, seperti pengakuan terhadap ke-esa-an Tuhan, malaikat, kitab-kitab suci yang diturunkan Tuhan, nabi-nabi, hari

\footnotetext{
25John C. Blair, The Sources of Islam, dibahasaarabkan oleh Mālik Muslimānī, Mashādir al-Islām (Colombo-India: The Cristian Literature Society for India, 1925), h. 16.

${ }^{26} \mathrm{Abu}$ al-Mundhir Hisham al-Kalbi, Kitāb al-Așnām, cet. IV (Kairo: Dār al-Kutub al-Mișriyyah, 2000),h. 11.

${ }^{27}$ Sayyid Mahmūd al-Qimnī, al-Hizb al-Hāshimī wa Ta sìs al-Dawlah al-Islāmiyyah, cet. IV (Kairo: Maktabah Madbūili al-Ṣaghīr, 1996), h. 119.
} 
kebangkitan dan penghitungan amal (al-ba'th wa yawm al-hisāb), surga dan neraka (al-jannah wa I-nār), dan ketetapan Tuhan (al-qadar aw qa dạ̄' Allah).

Ajaran-ajaran pokok atau yang dikemudian hari disebut dengan rukun Islam memang tidak sepenuhnya berasal dari Yahudi, namun apabila diprosentase maka kontribusi Yahudi lebih besar. ${ }^{28} \mathrm{Hal}$ ini dapat dimengerti mengingat Nabi Muhammad dibesarkan dan dididik oleh Abdul Muțalib yang dalam kepemimpinannya mentransformasi ajaran-ajaran Yahudi ke dalam agama Hanīfiyyah yang kemudian dilanjutkan oleh anaknya, yakni Abū Țālib yang sangat taat mengamalkan ajaran warisan ayahnya.

Menurut Theodor Noldeke, konsep kenabian sendiri hanya berkembang di kalangan bangsa Israel (Yahudi), meski konsep yang hampir serupa dengannya dapat ditemukan dalam bangsa-bangsa yang lain. ${ }^{29}$ Deklarasi kenabian yang dilakukan Nabi Muhammad tidak lepas dari pergumulannya dengan orang-orang Yahudi, atau minimal karena secara umum ajaran-ajaran Yahudi sudah sangat mengakar kuat dalam diri Nabi Muhammad dan masyarakat Makkah.

Noldeke seperti dikutip Wolfensohn menyimpulkan, bahwa ayat-ayat alQur'an yang turun sebelum Nabi Muhammad hijrah ke Madinah selaras dengan ajaran-ajaran Taurat. Orang-orang Makkah sangat akrab dengan ajaran-ajaran Yahudi, sehingga al-Qur'an menyatakan bahwa isinya sama dengan kitab yang diterima Ibrahim dan Musa. ${ }^{30}$

Dalam al-Qur'an surat al-A'lā dinyatakan:

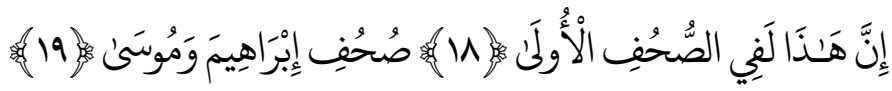

\footnotetext{
${ }^{28}$ John C. Blair dalam bukunya, The Sources of Islam, menyimpulkan bahwa agama Nabi Muhammad bersumber pada semua agama yang berkembang di dalam masyarakat Arab, yaitu Yahudi, Kristen, Shābi în, Majusi, dan yang lainnya. John C. Blair, The Sources of Islam, diarabkan oleh Mālik Muslimānī, Mashādir al-Islām (Colombo-India: The Cristian Literature Society for India, 1925)

${ }^{29}$ Theodor Noldeke, Geschichte des Qur'ans, diarabkan oleh Georges Tamer, Tärīkh al-Qur'ān , cet. I (Beirut: Konrad Adenauer Stiftung, 2004), h. 3.

${ }^{30}$ Israel Wolfensohn, Tārīkh al-Yahūdfi Bilād al-'Arab fi I-Jāhilìyah wa Șadral-Islām, h. 95.
} 
"Sesungguhnya ini benar-benar terdapat dalam kitab-kitab yang dahulu, (yaitu) kitab-kitab Ibrahim dan Musa." ${ }^{31}$

Al-Qur'an juga menegaskan kepada penduduk Makkah bahwa Nabi Muhammad bagi bangsa Arab sama seperti Nabi Musa bagi bangsa Israel. Apabila bangsa Arab tidak patuh terhadap Muhammad, maka akan ditimpa bencana sebagaimana Fir'aun dan pengikutnya yang memusuhi Nabi Musa.

Dalam QS. al-Muzzammil 15-16 dinyatakan:

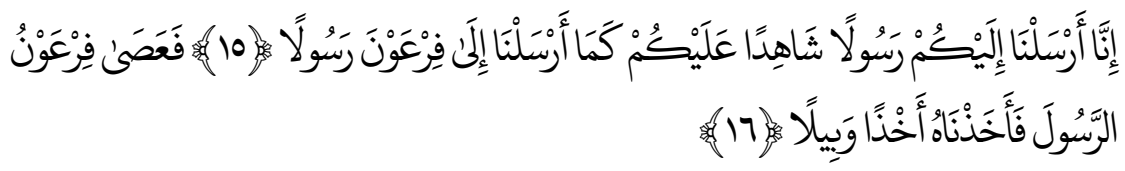

"Sesungguhnya Kami telah mengutus kepada kalian seorang utusan yang menjadi saksi terhadap kalian, sebagaimana Kami telah mengutus seorang utusan kepada Fir'aun. Maka Fir'aun mendurhakai utusan itu, lalu Kami siksa dia dengan siksaan yang berat."32

Menurut John C. Blair, pengetahuan Nabi Muhammad tentang Talmud yang didapat dari pendeta Yahudi sangat membantu konsep tauhid yang diserukannya. ${ }^{33}$ Internalisasi ajaran Yahudi terhadap diri Nabi Muhammad ini tidak hanya melalui Abdul Muțalib dan Abū Țālib, tapi juga didapatkan secara langsung dari orang-orang Yahudi yang ditemui Nabi ketika mengelola perdagangan milik Khadijjah sebelum menjadi istrinya. Hal ini masuk akal karena jaringan perdagangan Makkah dengan Yahudi Madinah dan Khaibar saat itu sangat kuat. ${ }^{34}$

Keyakinan tentang malaikat yang dimiliki dan ditawarkan Nabi juga diambil dari keyakinan orang-orang Yahudi. Sosok Jibril yang diimani Nabi sebagai pengantar wahyu, terdapat dalam kitab Taurat. ${ }^{35}$ Begitu juga terkait hari kebangkitan dan pertimbangan amal perbuatan dapat ditelusuri dalam

\footnotetext{
31 QS. al-A'lā: 18-19.

${ }^{32}$ QS. al-Muzzammil: 15-16.

33 John C. Blair, The Sources of Islam, h. 29-30.

${ }^{34}$ Israel Wolfensohn, Tārïkh al-Yahūd fí Bilād al-'Arab fi I-Jāhiliyyah wa Șadral-Islām, h. 94.

35John C. Blair, The Sources of Islam, h. 36-37.
} 
kitab orang-orang Yahudi. ${ }^{36}$ Konsep surga dan neraka berikut gaya penyampaiannya yang sarat metafor, Nabi mengambilnya dari sastra Yahudi. ${ }^{37}$

Dari sini dapat dimengerti bahwa kontribusi Yahudi terhadap diri Nabi Muhammad pada periode Makkah berupa paham keagamaan yang di kemudian hari dapat dijadikan sebagai alat atau cara oleh Nabi untuk meraih kekuasaan. Berbeda dengan periode Makkah, ketika Nabi Muhammad hijrah ke Madinah kontribusi Yahudi sangat jelas berupa kekuatan yang sangat membantu bagi berjalannya kekuasaan Nabi.

Masa-masa awal di Madinah Nabi Muhammad banyak mengikuti keyakinan Yahudi dalam rangka menggalang simpatinya, seperti ikut serta menjalankan puasa, shalat menghadap ke Bait al-Maqdis, memperbolehkan memakan makanan yang dihalalkan orang-orang Yahudi, dan menikahi wanita-wanitanya.

Ibnu 'Abbās menceritakan, ketika Nabi Muhammad hijrah ke Madinah, Nabi melihat orang-orang Yahudi menjalankan puasa pada hari 'Asyūrā' dalam rangka memperingati hari diselamatkannya orang-orang Yahudi (Bani Israel) dari musuh-musuhnya. Lalu Nabi menyuruh pengikutnya untuk ikut serta berpuasa pada hari itu. ${ }^{38}$

Demikian juga dengan shalat yang menghadap ke bait al-maqdis mengikuti orang-orang Yahudi yang juga menghadap ke arah yang sama. Namun di kemudian hari ketika pengikut Nabi sudah banyak, Nabi memindahkan kiblatnya ke Makkah sebagai bentuk penentangan terhadap Yahudi yang tidak patuh terhadap kekuasaan Nabi.

Berkaitan dengan makanan dan menikahi wanita Yahudi, QS. al-Mā̄idah: 5 menegaskan bahwa makanan atau binatang sembelihan orang-orang yang diberi Kitab (Yahudi) halal bagi pengikut Nabi Muhammad, sebagaimana makanan (binatang sembelihan) pengikut Nabi juga halal bagi Yahudi. Demikian juga boleh menikahi wanita-wanita Yahudi.

\footnotetext{
36Ibid, h. 67.

${ }^{37} \mathrm{Ibid}$, h. 78.

38al-Bukhārī, Șaḥịh al-Bukhārī, cet. I, vol. III (Beirut: Dār Ṭūq al-Najāh, 1422 H), h. 44.
} 
Tujuan Nabi Muhammad mengadopsi ajaran-ajaran Yahudi karena Nabi berharap simpati dari orang-orang Yahudi, hingga kemudian Yahudi dapat membantu berlangsungnya proses kekuasaan yang sedang berlangsung dibangunnya.

Di atas bagian dari kontribusi Yahudi terhadap Nabi Muhammad dalam ideologi atau ajaran agama. Sedangkan kontribusinya dalam bidang materi yang menjadi kekuatan utama bagi kekuasaan Nabi sangat banyak seperti yang akan dijelaskan nanti. Tanpa ada orang-orang Yahudi di Madinah, Nabi tidak mungkin hijrah ke kota ini meski Nabi memiliki saudara-saudara dari keluarga kakeknya, yakni suku Khazraj.

Tiga keluarga besar Yahudi di Madinah, yakni Bani Qainuqā', Bani al-Nadịir, dan Bani Quraidah, menjadi faktor utama yang mendorong Nabi Muhammad memilih hijrah ke Madinah. Selain orang-orang Yahudi di Madinah memiliki kelas sosial tinggi, kaya raya, juga memiliki keselarasan paham agama yang dimiliki Nabi Muhammad yang didapat dari Abdul Muțalib dan Abū Țālib, yaitu sama-sama menentang penyekutuan terhadap Tuhan.

Khalīl Abdul Karīm mengatakan:

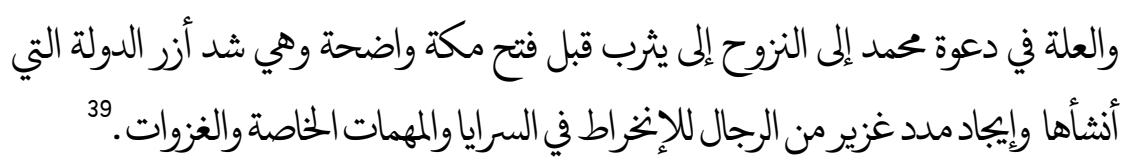

"Alasan yang mendasari Nabi Muhammad menyeru (kepada pasukannya) untuk pindah ke Yathrib sebelum penaklukan Makkah sangat jelas, yaitu memperkuat kekuatan kekuasaan yang sedang dibangunnya, dan mendapatkan bantuan harta benda dari orang-orang untuk pembiayaan pasukan perang, berbagai kepentingan khusus, dan peperangan."

Kondisi sosial dan politik Yahudi di Madinah yang berbasis pada benteng mendorong Nabi untuk melakukan perjanjian damai atau kesepatakan bersekutu dengannya. Keluarga-keluarga yang ada di dalam benteng memiliki kepekaan sosial tinggi, yaitu tolong menolong. Karena itu dengan mengadakan perjanjian damai dengan penguasa atau pemilik benteng, yakni orang-orang

\footnotetext{
${ }^{39}$ Khalīl Abdul Karīm, Dawlah Yathrib; Bashā ïr fi 'Ām al-Wufūd wa fi Akhbārih, cet. I (Kairo: Sīnā li al-Nasyr, 1999), h. 75.
} 
Yahudi, Nabi Muhammad dan pasukannya mendapatkan pertolongan dari mereka untuk menghadapi orang-orang Quraish dan menjadi kekuatan tersendiri bagi kekuasaan yang sedang dicita-citakannya.

Peperangan yang dilakukan Nabi Muhammad melawan orang-orang Quraish tidak lepas dari bantuan orang-orang Yahudi, baik materi, pikiran maupun tenaga. Pada perang Uhud, Nabi Muhammad secara terang-terangan meminta bantuan kepada orang Yahudi, khususnya Yahudi Bani al-Nadiir. Kendati Bani al-Nadiir secara umum tidak membantunya karena bertepatan dengan hari Sabat, namun ada salah satu pemuka Yahudi yang ikut terlibat, yaitu Mukhairīq.

Ibnu Isḥāq menginformasikan, Mukhairīq adalah pendeta Yahudi yang pintar, kaya, dan memiliki kebun kurma yang sangat luas. Mukhairīq simpati dengan Nabi Muhammad hingga ketika Nabi hendak melakukan peperangan melawan orang-orang Quraish di Uhud yang bertepatan dengan Hari Sabat (yaum al-sabat), Mukhairīq menyeru kepada umatnya:

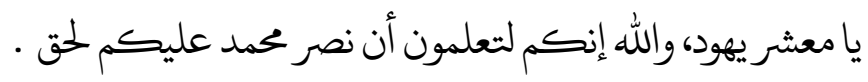

"Wahai orang-orang Yahudi, demi Allah sesungguhnya kalian tahu bahwa menolong Muhammad bagi kalian adalah suatu kewajiban."

Orang-orang Yahudi menjawab, bahwa hari itu adalah Hari Sabat. Kepada orang-orang Yahudi, Mukhairīq menegaskan bahwa Hari Sabat diliburkan. “Tidak ada Hari Sabat bagi kalian (لا سبت لكم),"kata Mukhairīq.

Lalu Mukhairīq mengambil pedang berangkat bersama orang-orang Yahudi yang mengikutinya menuju Uhud. Kepada pengikutnya, Mukhairīq berpesan: "Apabila pada hari ini aku terbunuh, maka semua hartaku diberikan إن قتلت هذا اليوم، ( kepada Muhammad untuk digunakan sesuai dengan izin Allah (فأمو الي لمحمد يصنع فيها ما أراه الله

Ketika peperangan berkecamuk, Mukhairīq ikut serta membantu Nabi Muhammad melawan orang-orang Quraish hingga Mukhairīq mati terbunuh. Menyaksikan kejadian itu, Nabi Muhammad bersabda: "Mukhairīq adalah sebaik-baik orang Yahudi (مخيريق خير يهود)."40

\footnotetext{
40Ibn Hishām, al-Sirrah al-Nabawiyyah, h. 518.
} 
Lalu Nabi Muhammad menerima semua harta kekayaan Mukhairīq seperti yang diamanatkan Mukhairīq kepada pengikutnya. Harta kekayaan ini kemudian digunakan Nabi untuk membiayai para pengikutnya di Madinah. Bahkan sebagian besar biaya kehidupan pengikut Nabi Muhammad di Madinah diambil dari harta kekayaan Mukhairīq.

Pernyataan Nabi Muhammad terhadap Mukhairīq sebagai orang Yahudi terbaik membuktikan bahwa Nabi meminta bantuan materi dan tenaga kepada orang-orang Yahudi, namun banyak di antara mereka yang tidak membantu.

Bantuan ide dan materi dari orang-orang Yahudi juga diberikan kepada Nabi Muhammad ketika kekuasaan Nabi hendak diserang pasukan gabungan (al-Ahzāb) yang terdiri dari Yahudi Bani al-Nadīir, pasukan Quraish, dan suku Ghathafān. Yahudi Bani Quraiḍah menyampaikan ide untuk membuat parit (khandaq), lalu Nabi Muhammad menerima dan meminjam alat-alat untuk menggalinya.

Selain itu benteng-benteng milik Yahudi Bani Quraiḍah juga digunakan sebagai benteng pertahanan pasukan Nabi Muhammad. Jadi meski Bani Quraidah dalam kesepakatannya dengan Nabi tidak disyaratkan ikut serta terlibat dalam peperangan yang dilakukan Nabi di luar Madinah, namun dalam perang ini Yahudi Bani Quraidah menyokong tentara Nabi dengan materi dan gagasan besar yang menjadikan pasukan musuh Nabi tidak dapat menembus Madinah.

Kedatangan Nabi Muhammad ke Madinah (hijrah) membawa kepentingan supaya orang-orang Yahudi membantu Nabi dalam menaklukkan suku Quraish. Sementara Yahudi sendiri mengharapkan kedatangan Nabi Muhammad bisa mempersatukan penduduk Madinah dan menciptakan kehidupan yang aman hingga Madinah dapat menjadi pusat perdagangan yang mengalahkan Makkah.

Nabi Muhammad dan pengikutnya pada masa-masa awal di Madinah hidup dalam keadaan miskin, tidak memiliki harta yang cukup untuk digunakan pengembangan kekuasaan. Kehidupan sehari-hari pasukan Nabi dari Makkah (Muhājirīn) ditanggung penduduk Madinah (Anșār). Harta kekayaan 
yang dimiliki Nabi Muhammad dari istrinya, Khadijah binti Khuwailid, kemungkinan besar habis ketika Nabi bermigrasi di Madinah.

Menarik untuk diungkap, bahwa gerakan Nabi Muhammad dalam menggalang massa untuk mewujudkan kekuasaan membutuhkan biaya yang sangat banyak. Biaya ini diambil dari harta kekayaan istrinya, Khadijah. Henry Massie seperti dikutip Syākir al-Nābulisī menyatakan, peran Khadījah dalam penyebaran Islam, yakni dalam pembentukan kekuasaan Nabi Muhammad sangat besar sekali. Sejak perekrutan massa di Makkah Nabi Muhammad harus membiayai orang-orang miskin, membekali para pengikutnya supaya dapat mengajak orang lain untuk ikut serta bergabung dengan Nabi , membeli budak untuk memerdekakannya, dan yang lainnya, hingga sisanya dihabiskan di Madinah. ${ }^{41}$

Karena itu imigrasi Nabi Muhammad ke Madinah merupakan langkah cerdas dalam upaya mewujudkan kekuasaan. Di Madinah Nabi dapat meminta bantuan kepada penduduknya, terutama dalam pendanaan. Berkaitan dengan hal ini, Syākir al-Nābulisī mengatakan:

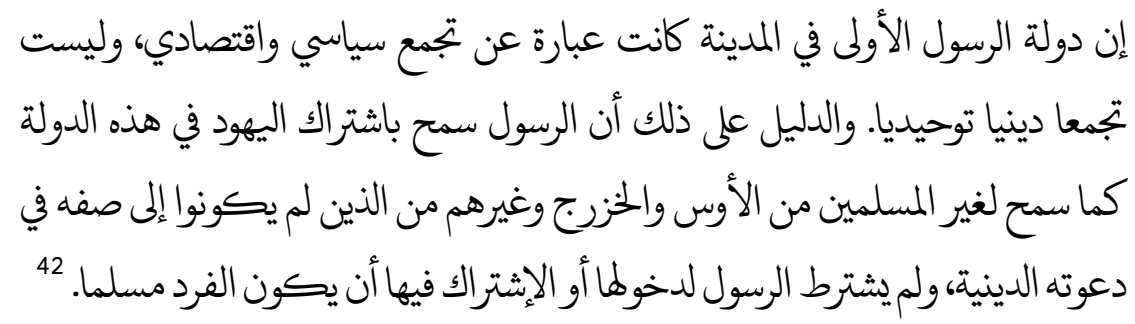

"Kekuasaan perdana Nabi Muhammad di Madinah adalah penjelasan tentang perkumpulan politik dan ekonomi, bukan perkumpulan agama monoteis. Dasar yang menunjukkan hal itu ialah Nabi Muhammad menerima keterlibatan orangorang Yahudi dalam kekuasaannya. Sebagaimana Nabi juga mentoleransi nonMuslim dari suku Aus, Khazraj, dan suku lainnya yang tidak sepaham dengan Nabi Muhammad dalam persoalan agama. Nabi tidak mensyaratkan orangorang yang bergabung atau terlibat di dalam kekuasaannya harus Muslim."

\footnotetext{
${ }^{41}$ Lihat catatan kaki Syākir al-Nābulisī, al-Māl wa I-Hilāl; al-Mawāni' wa I-Dawāfi' a-Iqtișādiyyah li Zuhūr al-Islām, cet. I (Beirut: Dār al-Sāqī, 2002), h. 127.

${ }^{42}$ Ibid, h. 128.
} 
Penjelasan al-Nābulisī di atas menguatkan terhadap pandangan bahwa hijrah Nabi Muhammad ke Madinah memiliki kepentingan dua arah sekaligus, yaitu kepentingan Nabi sebagai pendatang dan kepentingan Yahudi sebagai penduduk setempat. Kepentingan Nabi berupa keinginan mewujudkan kekuasaan dengan basis ekonomi dan militer dari Yahudi dan penduduk Madinah lainnya, sedangkan kepentingan Yahudi ingin mewujudkan Madinah sebagai pusat perdagangan yang dapat mengalahkan Makkah.

Dua kepentingan yang tidak dapat disatukan itu dalam perjalanannya mengantarkan pada keadaan saling curiga. Orang-orang Yahudi yang mulanya menanti kedatangan Nabi sebagai orang yang dapat mempersatukan penduduk Madinah dan menciptakan Madinah sebagai kota yang aman mulai merasa kecewa dengan langkah Nabi Muhammad yang ternyata sedang berusaha membangun kekuasaan yang mengharuskan orang-orang Yahudi tunduk ke dalam kepemimpinannya.

Langkah Nabi Muhammad yang semakin menguasai Madinah mulai disikapi Yahudi Bani Qainuqā' dengan memutus bantuan yang diberikan kepada Nabi Muhammad dan pasukannya. Imigran Makkah yang menjadi pengikut Nabi hidup dalam keadaan miskin dengan menggantungkan hidupnya pada keluarga Nabi di kota ini, yakni dari suku Khazraj (sahabat Anșār).

Kendati hubungan Nabi Muhammad dengan Yahudi sejak terjadi persinggungan kepentingan politik menjadi dingin, namun Yahudi tetap menjaga stabilitas keamanan Madinah demi menyelamatkan perekonomiannya. Demikian juga dengan sikap Nabi Muhammad, tidak segera melakukan tindakan represif sebagaimana yang terjadi setelahnya.

Kondisi buruk, terutama dalam bidang ekonomi yang dialami Nabi Muhammad dan pengikutnya mendorong Nabi menghadang kafilah dagang Quraish yang hendak ke Syām di Badar. Kafilah dagang yang berhasil dijarah yaitu milik Abū Sufyān, salah seorang pemuka Quraish yang kaya raya. ${ }^{43}$ Di

\footnotetext{
${ }^{43}$ Menurut Sayyid Maḥmūd al-Qimnī, Perang Badar bagian dari cara Nabi Muhammad membuktikan kepada orang-orang Yahudi Madinah bahwa dirinya meskipun tidak memiliki kekayaan yang cukup, tapi memiliki pengetahuan yang bisa dijadikan bekal untuk menjadi pemimpin, sebagaimana kisah Ṭālūt yang tak punya harta tapi diutus Allah untuk menjadi raja. Ulasan al-Qimnī
} 
Badar pasukan Nabi Muhammad berhasil mengalahkan orang-orang Quraish dan menjarah harta dagangannya hingga kemudian menjadi bekal represi terhadap orang-orang Yahudi. ${ }^{44}$

Bani Qainuqā' menjadi sasaran utama kelompok Yahudi yang direpresi Nabi Muhammad lantaran keberadaannya yang mudah dijangkau dan harta kekayaannya yang banyak disimpan di dalam rumah. Bani Qainuqā' diusir dari Madinah dan harta kekayaannya diambil oleh Nabi Muhammad untuk membiayai pasukannya, terutama dari imigran Makkah.

Menurut Jawād Ali, alasan yang menjadikan Bani Qainuqā' diusir karena Bani Qainuqā’' mendukung orang-orang Quraish dalam Perang Badar. Alasan ini menguatkan pada pemahaman konflik Yahudi Bani Qainuqā’ dengan Nabi Muhammad sebelum terjadi perang Badar, yakni karena Yahudi Bani Qainuqā’ merasa kecewa dengan langkah Nabi Muhammad, maka Bani Qainuqā' lebih mendukung orang-orang Quraish meski keberadaannya sebagai saingan Yahudi dalam perdagangan.

Pasca penyerangan terhadap orang-orang Quraish di Badar dan pengusiran Yahudi Bani Qainuqā', Nabi Muhammad terus memperlihatkan otoritasnya sebagai orang yang berkuasa di Madinah. Hal ini terus berlanjut hingga kemudian dua kelompok Yahudi besar lainnya, yakni Bani al-Nadlīr dan Bani Quraidhah juga harus menginjakkan kaki dari tanah yang sudah ratusan tahun dihuni sejak nenek moyangnya.

Pasca pengusiran tiga kelompok Yahudi besar di Madinah, Nabi Muhammad menjadi orang yang memiliki otoritas tunggal dalam kekuasaan. Orangorang munāfiq, yakni orang yang lahiriahnya memperlihatkan ketaatan terhadap Nabi Muhammad, namun di belakang Nabi merencanakan pemberontakan tidak ada lagi yang berani bersuara secara terang-terangan.

terhadap Perang Badar sangat menarik, memperlihatkan bagaimana Nabi Muhammad dapat mempercayakan orang-orang Yahudi dengan kisah Țālut yang ada di dalam tradisi Yahudi. Baca Sayyid Maḥmūd al-Qimnī, Ḥurūb Dawlah al-Rasūl, cet. II, vol. I (Maktabah Madbūlī al-Ṣaghīr, 1996), h. 47-118.

${ }^{44}$ Israel Wolfensohn, Tārīkh al-Yahūd fi Bilād al-'Arab fi I-Jāhiliyyah wa Shadr al-Islām, h. 127. 
Madinah secara utuh berada dalam kekuasaan Nabi Muhammad. Harta kekayaan milik orang-orang Yahudi yang ada di Madinah pada akhirnya jatuh ke tangan Nabi dan menjadi bekal utama dalam perluasan wilayah kekuasaan selanjutnya. Sejak di Makkah Nabi Muhammad menjanjikan kepada pengikutnya bahwa harta kekayaan Kisra dan Kaisar akan terkuasai. Karena itu Nabi terus melancarkan serangan militer ke berbagai wilayah di jazirah Arab hingga kemudian Arab berada dalam genggamannya secara keseluruhan.

Orang-orang Yahudi diusir dari Madinah karena melakukan perlawanan terhadap sikap politik Nabi Muhammad. Mungkin sejarah akan berbicara lain jika orang-orang Yahudi itu patuh terhadap kepemimpinan Nabi Muhammad atau menang dalam pertarungan politik.

Kekuasaan bisa terus berkembang dengan melakukan ekspansi ke luar meniscayakan orang-orang yang berada di dalamnya kompak dan patuh terhadap penguasanya. Madinah yang dijadikan sentral kekuasaan Nabi Muhammad mengharuskan penduduknya mendukung penuh terhadap kepemimpinan Nabi, sehingga dalam rangka mewujudkan kekuatan internal itu, Nabi terpaksa harus mengusir rakyat yang menolak kepemimpinannya.

Jadi konflik Nabi dengan Yahudi murni sebagai konflik politik, bukan konflik yang disebabkan perbedaan paham keagamaan atau kesukuan. Keberhasilan mengusir tiga kelompok besar Yahudi di Madinah tidak kemudian menjadikan Nabi melakukan hal yang sama terhadap semua Yahudi.

Begitu juga dengan sikap para pengikut Nabi Muhammad, selama seseorang patuh terhadap kekuasaan Nabi meskipun secara teologis berbeda maka tidak diserang. Kontribusi Yahudi terhadap kekuasaan Quraish terus berlanjut hingga Nabi Muhammad wafat, bahkan hingga kekuasaan Nabi dikendalikan oleh para penggantinya (khulafā'al-rāsyidūn).

\section{Kesimpulan}

Berdasarkan uraian dan analisis sejarah kekuasaan Nabi Muhammad di atas setidaknya ada dua kesimpulan penting yang dapat dijadikan kata kunci dalam memahami relasi Nabi Muhammad dengan Yahudi di Madinah.

Pertama, relasi politik Nabi Muhammad dengan Yahudi di Madinah adalah relasi timbal balik yang masing-masing memiliki kepentingan politik dan 
ekonomi. Hijrah Nabi Muhammad ke Madinah bertujuan supaya orang-orang Yahudi membantu Nabi dalam mewujudkan kekuasaan yang sedang berhadapan dengan orang-orang Quraish.

Kedua, kontribusi Yahudi terhadap kekuasaan yang diraih Nabi Muhammad sudah berlangsung lama melalui kakeknya yang bernama Abdul Muțalib. Kekuasaan Nabi Muhammad adalah kekuasaan yang dirintis dan terus dikembangkan oleh nenek moyang Nabi mulai dari Qushaiy ibn Kilāb yang kemudian diteruskan anaknya, Abdu al-Dār, dilanjutkan oleh Hāshim ibn Abdu Manāf, diteruskan oleh adiknya, al-Muțalib, berlanjut ke Abdul Muțalib, diteruskan anaknya yang bernama Abū Ṭālib hingga kemudian sampai kepada Nabi Muhammad dengan kekuasaan yang lebih luas dan digdaya. Kontribusi Yahudi terhadap "kekuasaan Nabi" pada masa pra Islam berupa ideologi, yakni tradisi dan ajaran agama Yahudi yang dipraktikkan oleh Abdul Muțalib untuk menggalang simpati masyarakat Makkah, dan materi berupa bantuan kekuatan militer selama Abdul Muțalib berkuasa. Sedangkan kontribusinya kepada Nabi Muhammad secara langsung selain tradisi dan ajaran Yahudi, juga materi yang sangat membantu bagi proses kekuasaan Nabi yang sedang berlangsung.[a]

\section{DAFTAR PUSTAKA}

'Abdul Karīm, Khalīl, Dawlah Yathrib; Bashā ìr fi 'Ām al-Wufūd wa fi Akhbārih, Kairo: Sinā li al-Nasyr, 1999.

Quraish min 7-Qabīlah ilā '1-Dawlah al-Markaziyyah, Kairo: Sīnā li alNasyr, 1997.

Abdullah, Zulkarnaini, Yahudi dalam al-Qur'an; Teks, Konteks, dan Diskursus Pluralisme Agama, Yogyakarta: Penerbit eLSAQ Press, 2007.

al-Atsīr, Ibnu, al-Kāmil fi at-Tārīkh, Beirut-Libanon: Dār al-Kitāb al-'Arabi, 1997.

Blair, John C., The Sources of Islam, diarabkan oleh Mālik Muslimānī, Mashādir al-Islām, Colombo-India: The Cristian Literature Society for India, 1925.

al-Bukhārī, Muhammad ibn Ismail, Sahịḥ al-Bukhārī, Beirut: Dār Thūq al-Najāh, $1422 \mathrm{H}$.

Busroh, Abu Daud, Ilmu Negara, Jakarta: Bumi Aksara, 2010.

AL-AHKAM

p-ISSN: 0854-4603; e-ISSN: 2502-3209

Volume 26, Nomor 2, Oktober 2016 || 201 
Hishām, Ibnu, al-Sïrah al-Nabawiyyah, Mesir: Syirkah Maktabah wa Maṭba'ah Mushthafā al-Bābī al-Halbī, 1955,

Humaidullah, Muḥammad, Majmū'ah al-Wathāìq al-Siyāsiyyah li al-'Ahdi alNabawiy wa l-Khilāfah al-Rāshidah, Beirut: Dār al-Nafāis, 1987.

al-Kalbi, Abū al-Mundhir Hisham, Kitāb al-Așnām, Kairo: Dār al-Kutub alMișriyyah, 2000.

al-Nabrāwī, Fathiyyah dan Muhammad Nașr Mihnā, Tațawwur al-Fỉkr al-Sìāsī fi al-Islām, Kairo: Dār al-Ma'ārif, 1984.

al-Nābulisī, Syākir, al-Māl wa al-Hilāl; al-Mawāni' wa I-Dawāfi' al-Iqtishādiyyah li Zuhūur al-Islām, Beirut: Dār al-Sāqī, 2002.

Noldeke, Theodor, Geschichte des Qur'ans, diarabkan oleh Georges Tamer, Tārīkh al-Qur'ān, Beirut: Konrad Adenauer Stiftung, 2004.

al-Qimnī, Sayyid Mahmūd, al-Hizb al-Hāshimī wa Ta sìs I-Dawlah al-Islāmiyyah, Kairo: Maktabah Madbūlī al-Saghīr, 1996.

Hurūb Dawlah al-Rasūl, Kairo: Maktabah Madbūlī al-Șaghīr, 1996.

al-Sayyid, Nāshir, Yahūdu Yathrib wa Khaibar: al-Ghazawāt wa '-Shirāh, Beirut: al-Maktabah al-Tsaqāfiyyah, 1992.

al-Syarif, Ahmad Ibrāhīm, Makkah wa I-Madīnah fi al-Jāhiliyyah wa 'Ahdi alRasūl, Beirut: Dār al-Fikr al-'Arabi, t.th.

Sirry, Mun'im, Kontroversi Islam Awal; Antara Mazhab Tradisionalis dan Revisionis, Bandung: Mizan Pustaka, 2015.

Watt, W. Montgomery, Muhammad Prophet and Statesman, diindonesiakan oleh A. Asnawi, Muhammad Sang Negarawan, Jogjakarta: Diglossia, 2007.

Wolfensohn, Israel, Tārīkh al-Yahūd fi Bilād al-'Arab fí al-Jāhiliyyah wa Shadr alIslām, Mesir: Maṭ ba'ah al-I'timād bi Shāri' Hasan al-Akbar, 1927. 